\title{
Between knowing and feeling: emotions and the vote in the 2017 Chilean presidential election
}

\author{
Carolina Segovia ${ }^{1}$ (iD \\ Ricardo Gamboa²
}

\begin{abstract}
How do citizens decide who to vote for in an election? Traditional answers focus on the role of political knowledge, party identification, and evaluations of the past performance of governments as explanatory variables. In this study we evaluate an alternative argument: the role of emotions. Using data from a survey carried out following the Chilean general elections of December 2017, this article investigates the association of emotions with the vote for Sebastián Piñera, and how emotions interact with other relevant factors that correlate with the vote. We conclude that in Chile, together with party identification and the evaluation of past governments, the emotions aroused by candidates are strongly associated with the voting decision.

Keywords: emotions; vote; party identification; political knowledge; retrospective evaluations; Chile
\end{abstract}

\section{Introduction $^{3}$}

How do citizens decide who to vote for in an election? Faced with the ballot paper, people must mark their preference for any of the candidates appearing on it in a process that lasts just a few seconds. Some voters will go through this process on election day, while others will have made their decision in advance. The literature on the vote in particular, on decision-making processes, or on the expression of opinions in politics in general, is extensive. As we will discuss later, research in this area has shown that people decide their vote according to basic predispositions like party identification (Campbell et al., 1960; Zaller, 1992), or voters' knowledge and evaluation of the candidates and their programs or proposals (Downs, 1957; Fiorina, 1981; Popkin and Dimock, 1999; Zaller, 1992). However, in contexts in which citizens have a low level of relevant political knowledge (Converse, 1964, 2000; Delli Carpini and Keeter, 1991; Gilens, 2012), and in

\footnotetext{
${ }^{1}$ Political Science Department - Universidad Diego Portales. Santiago (Metropolitan), Chile. E-mail: <carolina.segovia@udp.cl>.

2 Institute of International Studies - Universidad de Chile. Santiago (Metropolitan), Chile.

E-mail: <rgamboa@uchile.cl>.

3 This work was financed by Conicyt/Fondecyt grant \#1170335.
} 
which levels of political identification have fallen significantly, as they have in consolidated democracies (Andeweg and Farrell, 2017; Bargsted and Somma, 2016), neither of these two theoretical currents seems sufficient to explain how people vote.

From the field of political psychology, however, a third explanation has been proposed. Without denying the existence of voters who base their decision on basic predispositions or on cognitive processes involving evaluation of the proposals and candidates (Brader and Marcus, 2013; Groenendyk, 2011; MacKuen et al., 2007), it contributes important elements to explain the processes of political decision-making. These theories are based on the importance assigned to emotions and the role they play in the expression of opinion and decision-making in politics (Mackuen et al., 2007; Neuman et al., 2007; Valentino et al., 2011). Indeed, research has shown that when people make a political decision or give a political opinion they make use, not only of what they know and think, but also of what they feel about the different issues and political processes.

In this paper we study if and how, along with other traditional variables such as party identification, evaluation of the outgoing government and political knowledge, citizens rely on their emotions towards candidates in making the decision to vote. On the one hand, we expect that emotions aroused by candidates are associated with the vote (Lerner and Keltner, 2000): people are said to vote for those candidates who produce positive emotions in them, and to avoid voting for those who provoke negative emotions (Marcus, Neuman, and MacKuen, 2000). On the other hand, emotions are expected to have an indirect role on the vote, by interacting with other determinants of the vote and specifying the type of strategy that voters will use in their decision-making process (Mackuen et al., 2007). Emotions, then, come into play as moderators of other cognitive and affective considerations (such as party identification) that explain the voting decision (Druckman and McDermott, 2008; Lerner et al., 2015, Marcus, Neuman and Mackuen, 2000). In this paper we investigate, therefore, how emotions correlate with the vote and with other factors in citizens' voting choices.

To test our hypotheses, we used the data obtained in a survey conducted after the second round of the 2017 presidential election in Chile. We analyzed the relationship of emotions with the decision to vote for the president-elect, Sebastián Piñera. Chile is an excellent case to address the question posed. On the one hand, it is a consolidated democracy in which electoral processes work smoothly. In fact, the country receives high marks in comparative studies on democratic development (The Economist, 2018; Freedom House, 2018). Second, it is a presidential democracy, which allows the analysis to focus on a first-order election. Finally, as we explain later, appeals to emotions during the electoral contest were present in the various campaigns, and particularly in that of Piñera. Chile, therefore, is an appropriate case for the analysis presented here.

The results show that emotions toward a candidate are associated with the probability of voting for that candidate. Our evidence indicates, as expected, that the probability of a vote for Piñera increases in positive emotion scenarios and decreases in 
contexts of negative emotions. We also observe that the emotions that show the greatest association with the vote are anger and optimism, particularly the latter. Finally, the results show that emotions also mediate the role that other factors play with regard to the vote decision, the most important being the interaction between emotions and the evaluation of the previous government. Overall, the results indicate that emotions are associated with the voting decision and that they also mediate the correlation of other -and more traditional- factors that explain the vote.

The article is organized as follows. In the first section, "Determinants of the vote: three approaches", we briefly discuss the literature on the factors that determine the vote, and we develop an argument that incorporates emotions as relevant explanatory variables. In the second section, we describe "Data and methods" used. Then we present and discuss the "Results" obtained. We end with some "Conclusions".

\section{Determinants of the vote: three approaches}

How do citizens make political decisions? How do they decide which candidate to vote for? Given the centrality of the vote in democratic theory, the way in which citizens decide how and for whom to vote has become a central research question. Democratic theory sets high standards for citizens. According to Berelson, Lazarsfeld, and McPhee (1954, p. 308), for example, the democratic citizen is expected to be well informed about political issues in order to have the requisite knowledge to make good decisions. At the same time, however, research results have shown that this ideal is far from met in election periods (Gilens, 2012). In this context of low levels of information, two central theories have been developed in political science to explain the vote (Redlawsk and Pierce, 2017). Both models spring from the observation that citizens know very little about politics, and that in general they do not measure up to the bar in political sophistication that seems necessary for voting (Campbell et al., 1960).

In the first model it is postulated that the vote (and other political decisions) depend on basic predispositions, particularly party identification, that have been learned from an early age and that allow us to make decisions without much thought (Krampen, 2000; Sears and Brown, 2013; Zaller, 1992). Faced by ignorance of the candidates and their public policy proposals, it is enough for the voter to know who represents the political party they identify with and to choose in line with that predisposition (Druckman and Lupia, 2000; Gilens, 2012; Lau and Redlawsk, 2006; Lupia, 1994).

Research has shown consistently that party identification is one of the most important determinants of voting, both in contexts of consolidated democracies (Green and Baltes, 2017) and in countries with more recent democratic histories (Lupu, 2015). Identification with a party learned in the first years of political socialization tends to have lasting effects over time, allowing the vote to be predictable and stable from one election to another, absent other variables (Dinas, 2017; Hetherington, 2016). 
One problem with this model, however, is the assumption that voters -or at least a majority of them- have in fact come to identify with some group, party or political position. Where levels of political identification are low, as in the case of Chile (Bargsted and Somma, 2016), this theory can explain only a small fraction of the preferences expressed on election day. In fact, it has been observed that the vote is more unstable and more difficult to predict in contexts where the party system is weak and generates few ties with citizens that allow for stable preferences over time (Mainwaring and Torcal, 2006). In these contexts, study of voting decisions requires the consideration of other factors that shed light on the process.

The second model postulates that citizens consider rationally the electoral alternatives presented to them, choosing among those representing or responding best to their interests (Chong, 2013; Elster, 2007; Fiorina, 1981). In particular, the idea of an economic vote is raised, in which people vote for those considered to be responsible for past economic performance (the retrospective vote). In these rational choice theories, there is also a need for less knowledge than that required by democratic theory, with special emphasis on the definition of one's own interests as a threshold for the decision (Kinder, 1998).

The evaluation of past economic performance or the previous government can also be understood as a shortcut that reduces the need for information. In effect, it has been shown that people use these evaluations to decide their vote: if the previous government is well evaluated, the likelihood of voting for the same party increases. Likewise, if the evaluation of previous government's performance is poor, we would expect an increase in the likelihood of voting for the opposing party (Fiorina, 1981). Evidence has been found that provides important support for this theory (Lewis-Beck and Costa Lobo, 2017), although its role seems to be mediated by other factors, including party identification and the possibility of attributing responsibility to the government (Silva and Whitten, 2017). However, its effectiveness also depends on the importance that citizens attribute to economic management when deciding their vote (Gélineau and Singer, 2015). It has been observed, for example, that other issues may be more relevant and may reduce the role of retrospective voting (Pérez, 2015).

What the theory of party identification and economic voting share is the emphasis they put on cognitive or rational aspects in the decision-making process. Although party identification also includes affective elements (Campbell, 1960), emphasis has been placed on its cognitive dimension. This emphasis on cognitive aspects has been debated in the last 20 or 30 years and researchers have begun to include other variables in the analysis of decision-making processes that take into consideration other characteristics of people. Thus, it has been noted that emotions - and also other aspects such as personality - have begun to be used in the field of political science to explain phenomena such as voting, political participation, and opinions about groups, as well as other issues (Groenendyk, 2011). 
Using voting theories that incorporate the role of emotions is important in this context, as they allow inclusion in the decision of elements that go beyond individual cognitive processes. In particular, the theory of affective intelligence (developed by Marcus, Neuman and Mackuen, 2000), which is based on the appraisal theory of emotions (Moors et al., 2013), and the theory developed by Lodge and Taber (2013) which is based on research into online processing, motivated reasoning, and hot cognition (Lau and Redlawsk, 2006; Lerner et al., 2015; Lodge and Taber, 2013), allow an explanation of the vote that, without neglecting the factors mentioned above, incorporate them into a general model in which emotions and affects play a central role (Brader, 2012; Brader and Marcus, 2013; Groenendyk, 2011). Although these theories differ in important respects, they agree on the role that emotions have on the vote. Thus, following these studies, we argue in this paper that emotions will have both a direct and an indirect association with the vote (Redlawsk and Pierce, 2017; Brader, 2012).

\section{The direct association of emotions with the vote}

Although or perhaps because emotions are part of our daily experiences, research has been little consistent in defining them (Dixon, 2012; Mulligan and Scherer, 2012; Scarantino, 2012; Demertzis, 2013). In general, however, we can find three central elements of any definition. First, emotions are a response to an object or event that is relevant to people: in other words, emotions are about something (Marcus, Neuman and Mackuen, 2000). It is possible, therefore, that people have emotional responses to candidates in an election, especially in one of major importance such as a presidential contest. This has been confirmed by empirical research showing that people have emotional reactions towards candidates (Abelson et al., 1982; Ottati, Steenbergen and Riggle, 1992; Capelos, 2013), and that these emotions have consequences for their attitudes and behaviors (Capelos, 2013). In other words, emotions towards candidates will be independent of the final voting decision.

Second, emotions are aroused before we arrive at a conscious evaluation of those same objects or events (Marcus, 2013), but for the former to be relevant regarding attitudes and behaviors they must reach a state of consciousness (Marcus, Neuman and MacKuen, 2000; Spezio and Adolphs, 2007). In this way, emotions can be related to the way we evaluate different objects or events (Marcus, Neuman and Mackuen, 2000; Capelos, 2013).

Finally, emotions are accompanied by the tendency to do something (whether the action materializes or not). In other words, they are motivational impulses (Brader, 2012, Marcus, Neuman and Mackuen, 2000, Neuman et al., 2007). This makes it reasonable to suppose that emotions towards the candidates will be associated with the voting decision. Specifically, it has been observed that certain emotions motivate political participation, whether through voting (Valentino et al., 2011) or other political activities (Sabucedo and 
Vilas, 2014; Weber, 2012; Valentino et al., 2011; Jasper, 2011, 2014), and the decision about who to vote for (Marcus and Mackuen, 1993; Inbar et al., 2012).

However, not all emotions seem to be relevant for political action (Brader, 2012). Indeed, research in this field has focused on the role of fear and anxiety ${ }^{4}$, as well as enthusiasm or optimism, anger, and pride (Brader, 2012). Some authors analyze these emotions grouped according to their valence (if they are positive or negative), assuming that their characteristics and results will be similar (Lodge and Taber, 2013). We follow a different strategy, by analyzing the characteristics and the role that each emotion has in particular (Capelos, 2013). The analysis of discrete emotions has the advantage of distinguishing the type of appraisal that is carried out and how these emotions are transformed into political attitudes and behaviors (Huddy et al., 2005; Yates, 2016). In addition, it has been found that emotions with the same valence, like anger and fear, have different political consequences, indicating the need for a more systematic exploration of these differences (Huddy, Feldman and Cassese, 2007).

With respect to fear, it is argued that this occurs in the presence of a threat to people's well-being. Fear is experienced on those occasions where there is uncertainty about results and it can lead to citizens being more alert and more open to persuasion. It can also motivate escape from danger or a lesser inclination to accept risks (Brader, 2012; Lerner et al., 2015).

Anger, on the other hand, occurs when obstacles are seen to prevent the attainment of certain ends, or when others are perceived to have been harmed undeservedly. Anger, then, motivates people to remove obstacles, to punish aggressors, to be more prone to take risks, and to make compromise less possible (Brader, 2012; Lerner et al., 2015).

So, even though anger and fear are emotions that share the same valence and even appear to be related in observational studies, their origins and consequence are different (Huddy, Feldman and Cassese, 2007; Steenbergen and Ellis, 2006, p. 109-110; Petersen, 2010). Steenbergen and Ellis (2006), using survey data in the United States, for example, show that anger is a reaction to negative results such as an economic crisis or a political scandal that is blamed on the president or a political leader who is being evaluated. Fear, on the other hand, is generated in response to unusual or unexpected events (Rico, Guinjoan and Anduiza, 2017).

Enthusiasm or optimism, and pride, finally, are related emotions that have been less studied (Brader and Marcus 2013). The first occurs when progress is observed towards desired objectives. Pride emerges, on the other hand, when the objectives have been achieved, generating satisfaction (Yates, 2016). In the field of political action, enthusiasm and pride can increase motivation to pursue desired ends, lessen willingness to evaluate

\footnotetext{
${ }^{4}$ Fear and anxiety are used as equivalent concepts in the literature as we also do here.
} 
alternatives carefully, and inspire greater confidence in what is observed (Brader, 2012; Lerner et al., 2015).

Based on these definitions and on results observed in previous research, our first set of hypotheses refers to the direct role that these emotions will have on the vote. In general, we argue that emotions have a direct association with the decision of who to vote for. The emotions experienced towards the candidates, therefore, will be correlated with the election of the preferred candidate and the vote.

Fear occurs when a threat to wellbeing is perceived, generating a search for an escape from the threat. In an election, the way to escape from a threat is by voting for the opposing candidate. If a candidate is perceived as a threat, therefore, we expect the probability of voting for that candidate to diminish (Ottati, Steenbergen and Riggle, 1992; Miller, 2011; Druckman and McDermott, 2008).

H1a. The probability of voting for a candidate decreases when the candidate arouses fear.

Anger produced by the perception of obstacles or undeserved harm, on the other hand, leads to a search for the obstacle to be eliminated. If a candidate generates anger among the voters, therefore, we expect the probability of voting for that candidate to also diminish (Ottati, Steenbergen and Riggle, 1992; Miller, 2011; Druckman and McDermott, 2008).

H1b. The probability of voting for a candidate decreases when the candidate arouses anger.

If a candidate generates optimism or pride in the voters, people are expected, for their part, not to carefully evaluate the proposals of other candidates, to have greater confidence in the candidate in question, and therefore seek to maintain and continue with the desired objectives. Specifically, then, we expect that the probability of voting for a candidate is greater among those who feel pride or optimism towards that candidate (Miller, 2011; Yates, 2016; Just, Crigler and Belt, 2007; Druckman and McDermott, 2008).

H1c. The probability of voting for a candidate increases when the candidate arouses pride.

H1d. The probability of voting for a candidate increases when the candidate arouses optimism.

The indirect role of emotions on the vote

Research has also shown that emotions are indirectly associated with the vote. Indirect associations are those that occur when, aroused by different emotions, the role of other variables on the vote changes (Mackuen et al., 2007). In other words, emotions will also serve to alter the role of other cognitive considerations (knowledge, party identification and retrospective evaluation, in this case) that explain the choice of vote (Druckman and McDermott, 2008). 
According to Marcus, Neuman and MacKuen (2000), individuals' emotions determine whether, when evaluating political conditions and a future political decision, what these authors call the "disposition system" or the "surveillance system" is activated and used in the decision-making process. The disposition system is associated with emotions such as enthusiasm and pride. When activated, people will base their decisions on political predispositions (such as party identification) or on habit.

According to Marcus (2013), the disposition system "is a fast system" (p.26) that is activated in known or familiar circumstances, in which the most appropriate response is a previously learned one. From the point of view of political action, when the "disposition system" has been activated, people will base their decisions on customary or familiar elements. That is why in this type of case political actions will use elements such as party identification -a political predisposition- to decide the vote (Marcus, 2013).

The surveillance system, on the other hand, is one that is activated in situations of uncertainty generated by new or unusual circumstances and is generally associated with emotions such as fear or anger (Marcus, 2013). In these cases, people will be less guided by their habits, because fresh circumstances require new responses (Marcus, 2013). This leads to an increase in motivation to learn, to seek more information about different alternatives, and to be more attentive to changes in the environment. Consequently, in the political field it is expected that the vote will be associated with the analysis of the election's possible outcomes (Marcus, Neuman and MacKuen, 2000; MacKuen et al., 2007). This process, moreover, is determined by the events and vicissitudes of electoral campaigns (Lau and Redlawsk, 2006; Redlawsk, Civettini, and Lau, 2007). In the case of anger, which also activates the surveillance system, research has shown that it leads to an increase in the search for information, although this process is less cautious and could lead to accepting information that is incorrect (Marcus, 2013).

The indirect role of emotions, then, is likely to be associated fundamentally with how, and under what conditions, they interact with other determinants of the vote. In other words, emotions would be associated with the dimensions of the decision on which the individual will focus when conducting the evaluation, and on determining whether heuristics (such as party identification) or analytical processing will be used to make the decision (Lerner et al., 2015; Marcus, Neuman and Mackuen, 2000).

Empirical research provides evidence about these indirect associations. On the one hand, when the emotions that are activated are those related to the "disposition system" -optimism and pride-, then we should find that party identification and the evaluation of the previous government's performance have a stronger association with the vote decision, since these emotions reinforce previous beliefs or perceptions and lead subjects to make decisions based on habit (Lerner et al., 2015, Marcus Neuman and MacKuen, 2000). Marcus and Mackuen (1993) show that enthusiasm increases commitment to the campaign. Similar results were obtained by Valentino et al. (2008). 
On the other hand, Marcus, Neuman and MacKuen (2000), for example, have shown that fear about presidential candidates is associated with greater concern over the outcome of the election, more interest in the campaign, and more attention to news in the media (Ladd and Lenz, 2008; Marcus and MacKuen, 1993). The decision on the vote, then, would be based on a search of information and on cognitive processes that allow a more informed and reasoned decision to be made. In this way, it is expected that those emotions that activate the "surveillance system" will lead to a greater importance of political knowledge (Parker and Isbell, 2010; Ladd and Lenz, 2008; Weeks, 2015).

Based on these results, then, we expect that party identification and retrospective evaluations will play a more important role among those who express enthusiasm and pride toward the candidate. For those who feel anger or fear toward the candidate, we expect to find that knowledge has greater role on the vote.

H2a. In the presence of optimism or pride toward the candidate, the importance of partisan identification and retrospective evaluations on the vote will be greater than in the absence of such emotions.

H2b. In the presence of fear or anger toward the candidate, the importance of knowledge on the vote will be greater than in the absence of such emotions.

\section{Data and methods}

\section{Context of the study}

For the purposes of this study, some features of the 2017 presidential election need to be mentioned. First, the current president Sebastián Piñera was elected after two rounds (in Chile a ballotage system is used), since none of the eight participants in the first round obtained an absolute majority. Second, the range of contenders was particularly broad, with the participation of candidates of different ideological tendencies, from the far right to candidates with a very clear leftist position (Toro and Valenzuela, 2018). Third, even though all the candidates presented a clear electoral program, in fact the debate on specific public policies played a secondary role. This sparse debate revolved mainly around the success or failure of certain reforms implemented by the Bachelet government (education and taxation) and whether or not they needed to be modified.

In this context, Piñera focused much of his campaign on highlighting the negative effects of Bachelet's administration, especially with respect to economic growth, which was weak between 2014 and 2018. Hence, the main slogan of his campaign was "Lift up your hearts ... better times are coming," which is also a clear appeal to voters' optimism and enthusiasm. At the same time, it is worth noting that Piñera made an extensive use of images and symbols that seek to arouse pride among voters. For example, the use of the Chilean flag and other patriotic symbols in all of his public appearances. He also constantly appealed to pride with respect to his first government's achievements 
(www.sebastianpinera.cl). In a nutshell, both positive and negative emotions were a central part of his campaign.

Appeals to voters' emotions were also an important part of the other campaigns. A recent study (San Martín, 2018) analyzed the emotions that the candidates sought to arouse in voters through television propaganda, concentrating on three main ones: enthusiasm, anger, and fear. Two issues stand out in this regard: a) In all the campaigns, enthusiasm was the emotion most frequently invoked; b) Comparatively, Piñera was one of the two candidates with the highest percentage of messages devoted to generating voters' enthusiasm. Lastly, to this context of sparse programmatic discussion is added the fact that the election was held in a context of historically low levels of party identification ${ }^{5}$ (Bargsted and Somma, 2016), and very low levels of political knowledge, as in other democracies (Segovia, 2016).

The election was won by Sebastián Piñera, candidate of the right-wing coalition "Chile Vamos". In the first electoral round, he obtained $36.6 \%$ of the votes, followed by the ruling coalition candidate, Alejandro Guillier, with $22.7 \%$. In the second round, Piñera was elected with $54.7 \%$ of the votes. Turn-out reached $46.7 \%$ in the first round and $49.0 \%$ in the second.

\section{Participants}

For this study we use the results obtained in the Emociones y Politica (Emotions and Politics)(Segovia and Gamboa, 2018) survey, which was conducted immediately after the second round of the presidential election. This survey represents Chile's population over 18 years of age living in the country and includes both urban and rural areas. Two thousand people aged 18 and over were interviewed in their homes between December 18,2017 and January 31,2018 . Sampling error was estimated at $+/-2.2 \%$ on the assumption of maximum variance and for a $95 \%$ confidence level.

The sample selection method was probabilistic and proportional to population for each of the stages in which it was carried out: at a first stage, 110 communes were selected. In each region of the country the communes were ranked by population from the largest to the smallest; all the communes with more than 50,000 inhabitants (88 in number) were automatically included and a random sample of approximately 22 communes with less than 50,000 inhabitants was selected. The second stage involved the selection of residential blocks, which were chosen by stratified random sampling, with a probability of selection proportional to the size of the unit, in terms of the number of private homes it contained. In the third stage, private dwellings within each block were selected by systematic random sampling. Finally, the person to interview in each dwelling was

\footnotetext{
5 According to data from "Centro de Estudios Públicos" (CEP) surveys, for example, while in $199168 \%$ of respondents identified themselves with a political party, by the end of 2017 that percentage had fallen to $24 \%$.
} 
selected by using a Kish Table, which ensures that those eligible are chosen by a random procedure that ensures equal chances of selection.

The data collection was carried out through the application of face-to-face personal interviews in the participants' homes. These interviews were voluntary, the participants were informed that the results would be published, and they were assured of the confidentiality of personal information.

\section{Measurement}

The Emociones y Política survey questionnaire included questions aimed at measuring the vote in the 2017 election, as well as the emotions that the respondents felt about the candidates and other variables associated with the more traditional determinants of the vote.

Vote choice. The dependent variable was measured in questions about voting in the first and second round of the election. Since the vote has been voluntary in Chile since 2012, those who said they had voted in the presidential election, both in the first and second round, were asked "For which candidate did you vote?". The answers to these questions were recoded and changed into dummy variables, where 1 represents those who voted for Sebastián Piñera (the president-elect), and 0 those who voted for other candidates or who did not reply when asked for whom they voted (First round: $M=0.31$, $\mathrm{SD}=0.462$; second round: $M=0.43, \mathrm{SD}=0.495$ ).

Emotions. The emotions towards the candidates were measured using the following questions: "During the campaign, how often would you say you felt [afraid/angry/optimistic/ proud] of Sebastián Piñera, because of the type of person he is, or because of something he has done?" For each emotion considered, the values were recoded so that 1 represents those who state that they felt that emotion about Piñera, and 0 represents those who indicate that they did not feel it (Fear: $M=0.29, S D=0.454$, Anger: $M=0.41, S D=0.492$, Optimism: $M=0.40, S D=0.490$, Pride: $M=0.32, S D=$ 0.468).

Political knowledge. We measure political knowledge using three questions: (a) "As far as you know, how many deputies are elected in your district?"; (b) "In general, how long does a deputy serve in their post?"; (c) "Currently, who is the finance minister?". Correct answers were coded 1 ; incorrect and don't know answers were coded 0 . We then computed an additive index of political knowledge $(M=0.646, S D=0.754)$.

Party identification. Respondents were asked "Which political coalition represents your views best?". With these results we elaborated a dummy variable that indicates those who identify with the "Chile Vamos" coalition (the one that supported Piñera in the election and who governs with him) $(M=0.12, \mathrm{SD}=0.326)$.

Evaluation of previous government. Respondents were asked "Now thinking about the performance of the president in general, how good or bad a job do you think President 
Bachelet did over the last four years?". It is important to note that Sebastián Piñera is from the coalition opposed to the Bachelet government, so we expect there to be a negative relationship between a favorable evaluation of that government and the probability of a vote for Piñera. We computed a dummy variable indicating those who considered Bachelet's government to be good or very good $(M=0.58, S D=0.494)$.

Control variables. We included variables measuring the $\operatorname{sex}(M=0.48, S D=0.50)$, age $(M=44.49, S D=17.269)$, years of schooling $(M=12.02, S D=4.063)$, and socioeconomic status $(M=4.77, S D=1.54)$ of respondents.

\section{Data Analysis}

To evaluate the direct associations of emotions with the vote, we conducted two logistic regression models on the vote for Sebastián Piñera: one for the vote in the first round of the election, and another for the second round. To evaluate the indirect role of emotions, we estimated the marginal effects of the interaction between emotions and other relevant variables, and voting.

\section{Results}

What factors help to explain the vote for Piñera in the first and second rounds of the presidential election? As we noted earlier, the main theories of voting hold that citizens decide (a) according to their party identification and (b) according to their retrospective evaluation of the government or the economy. Both explanations require citizens to have some political knowledge. However, as in other consolidated democracies, Chilean voters declare a very low level of identification with parties and have little political knowledge, which leads to the conclusion that these two explanations on their own would be insufficient. Indeed, the results obtained show that $68 \%$ of respondents do not identify with any political coalition and that $50 \%$ do not answer correctly any of the questions included to measure political knowledge.

Chilean voters do mention, on the other hand, having felt emotions toward the candidates during the campaign. Regarding Sebastián Piñera, $29 \%$ felt fear, $41 \%$ felt anger, $40 \%$ felt optimism and $32 \%$ felt pride. In general, $73 \%$ of those interviewed said they felt at least one of these emotions towards the candidate.

\section{The direct association of emotions with vote decision}

To measure the association of emotions and other variables with the vote decision, we perform a logistic regression of them against the vote for Sebastián Piñera in the first and second electoral rounds. Table 1 presents the results obtained (logistic regression coefficients): 
Table 1

Logistic regression model on the vote for Piñera

\begin{tabular}{|c|c|c|c|c|}
\hline & \multicolumn{2}{|c|}{ First Round } & \multicolumn{2}{|c|}{ Second Round } \\
\hline & Coef. & $\begin{array}{c}\text { Robust Std. } \\
\text { Error }\end{array}$ & Coef. & $\begin{array}{c}\text { Robust Std. } \\
\text { Error }\end{array}$ \\
\hline $\begin{array}{l}\text { Evaluation of previous } \\
\text { government }\end{array}$ & $-0.990 * * *$ & 0.209 & $-1.239 * * *$ & 0.206 \\
\hline Party ID $(1=$ "Chile Vamos") & $1.450 * * *$ & 0.282 & $2.264 * * *$ & 0.356 \\
\hline Political knowledge & $-0.340 *$ & 0.140 & -0.194 & 0.133 \\
\hline Fear & $-1.167 * *$ & 0.344 & $-0.780 * *$ & 0.265 \\
\hline Anger & $-1.488^{* * *}$ & 0.287 & $-1.587 * * *$ & 0.238 \\
\hline Optimism & $1.673 * * *$ & 0.287 & $2.199 * * *$ & 0.272 \\
\hline Pride & $1.001 * * *$ & 0.281 & $1.056 * * *$ & 0.281 \\
\hline Gender $(1=$ male $)$ & -0.051 & 0.216 & -0.215 & 0.209 \\
\hline Age & 0.005 & 0.006 & -0.007 & 0.007 \\
\hline Years of schooling & -0.057 & 0.031 & 0.003 & 0.032 \\
\hline Socioeconomic status & $0.232 * *$ & 0.068 & $0.174 *$ & 0.076 \\
\hline Constant & $-1.615^{*}$ & 0.640 & -0.733 & 0.674 \\
\hline $\mathrm{N}$ & 1121 & & 1131 & \\
\hline Wald chi2 & $304.80 * * *$ & & $302.68^{* * *}$ & \\
\hline Pseudo R2 & 0.472 & & 0.537 & \\
\hline
\end{tabular}

Source: Emotions and Politics Survey, Chile, Dec. 2017 - Jan. 2018 (Segovia and Gamboa, 2018).

$* \mathrm{p}<0,05$; ** $\mathrm{p}<0,01 ; * * * \mathrm{p}<0,001$.

Based on the results shown in Table 1, we also computed the change in the probability of voting for Piñera when each variable changes from its minimum to its maximum value ${ }^{6}$. These results show that emotions towards the candidate are strongly correlated with the probability of a vote for Piñera, both in the first and in the second round. The results obtained for the first round indicate that the predicted probability of a vote for Piñera is 0.21 greater for individuals who felt optimism, and 0.12 greater for those who felt pride for the candidate. At the same time, the predicted probability of a vote for Piñera is 0.16 smaller for those in whom the candidate inspired anger and 0.12 smaller for those in whom he inspired fear. In other words, having felt emotions such as optimism and pride in Piñera increase the probability of a vote for him, ceteris paribus, while fear and anger decrease that probability in a statistically significant way, and in considerable magnitudes.

In the case of the second round, the predicted probability of a vote for Piñera is 0.30 greater for those who felt optimism and 0.12 greater for those who felt pride in him. Thus, optimism increases in importance as a determinant of the vote in the second round, while the importance of pride remains constant between one round and another. Regarding the role of anger and fear, the predicted probability of voting for Piñera is 0.17 smaller for those who felt anger and 0.07 for those who felt fear. As far as these emotions are concerned, then, in the case of anger the association remains constant between the two

\footnotetext{
${ }^{6}$ We estimated average marginal effects (AME) that is the mean of the marginal effects. According to Garson (2016), this measure is preferred when using factor variables, as we do here.
} 
electoral rounds, while fear has a weaker association to the vote in the second round. Overall, emotions have associations with the vote that are statistically significant and substantial in terms of their magnitude.

The associations of traditional variables, moreover, also show the expected results: controlling for other factors, the probability of a vote for Piñera increases among those who identify with the right-wing alliance "Chile Vamos" (Average Marginal Effects (AME) $=0.17$ in the first round, $A M E=0.26$ in the second round), and decreases significantly among those who express a positive evaluation of the Bachelet government (AME $=-0.11$ and -0.13 in the first and second rounds, respectively). The level of knowledge turns out to be of little importance. The coefficient is negative for both the first and second rounds, with those who voted for Piñera having, on average, less political knowledge. The coefficient, however, is statistically significant only for the first electoral round (AME = 0.03).

The control variables show no statistically significant associations with the vote, with the exception of the socioeconomic level of the interviewees. The probability of a vote for Piñera increases among those located higher on the social scale. These data are consistent with results obtained in other investigations that show that the vote for rightwing parties in Chile is higher in the most affluent sectors ${ }^{7}$.

\section{The indirect role of emotions on the vote}

To evaluate the indirect role of emotions we performed three logistic regression models against the vote for Piñera in the first and second electoral rounds. In each of these models, we use the same base model shown in Table 1, and we added interaction terms between emotions toward Piñera and the variables measuring party identification, evaluations of previous government's performance, and political knowledge. Table 2 presents the results obtained.

Our hypotheses indicated that the importance of party identification, political knowledge and the evaluation of the previous government on the vote would vary, depending on the emotions aroused by the candidate. In particular, we posit that the association of party identification and previous government's evaluation with the vote decision will be higher among those who feel optimism or pride toward Piñera $(\mathrm{H} 2 \mathrm{a})$. The association of political knowledge with the vote, on the other hand, will be higher among those who feel fear or anger toward Piñera $(\mathrm{H} 2 \mathrm{~b})$.

\footnotetext{
7 It might be argued that there is a problem of endogeneity between our dependent and independent variables. Research published elsewhere clearly discard this problem (see, for example, Marcus and Mackuen, 1993; Ottati, Steenbergen and Riggle, 1992; Inbar et al., 2012; Capelos, 2013; Huddy et al., 2005; Steenbergen and Ellis, 2006; Petersen, 2010). Nevertheless, we conducted 2SLS analysis of the data, testing different possible instrumental variables. We validated these instruments using Stata command estat endog. The results indicate that no endogeneity is observed in the data, so the hypothesis is rejected. Results are available upon request.
} 
Table 2

Logistic regression model on the vote for Piñera, with interactions (standard errors omitted)

\begin{tabular}{|c|c|c|c|c|c|c|}
\hline & \multicolumn{3}{|c|}{ First Round } & \multicolumn{3}{|c|}{ Second Round } \\
\hline & Model 1 & Model 2 & Model 3 & Model 1 & Model 2 & Model 3 \\
\hline $\begin{array}{l}\text { Eval. of previous } \\
\text { government }\end{array}$ & $-0.992 * * *$ & $-0.954 * * *$ & $-1.185 * *$ & $-1.253 * * *$ & $-1.233 * * *$ & $-1.217 * * *$ \\
\hline $\begin{array}{l}\text { Party ID }(1= \\
\text { "Chile Vamos") }\end{array}$ & $1.481 * *$ & $1.434 * * *$ & $1.478 * * *$ & $2.040 * * *$ & $2.261 * * *$ & $2.318^{* * *}$ \\
\hline $\begin{array}{l}\text { Political } \\
\text { knowledge }\end{array}$ & $-0.325^{*}$ & $-0.659 *$ & $-0.362^{*}$ & -0.183 & -0.256 & -0.225 \\
\hline Fear & $-1.240 * *$ & $-1.040 *$ & -0.784 & $-0.843 * *$ & $-0.742 *$ & $-1.081^{*}$ \\
\hline Anger & $-1.680 * * *$ & $-1.374 * * *$ & $-1.312 * *$ & $-1.664 * * *$ & $-1.683 * * *$ & $-0.990 * *$ \\
\hline Optimism & $1.715 * * *$ & $1.570 * * *$ & $0.856 *$ & $2.222 * * *$ & $2.255 * * *$ & $1.362 * * *$ \\
\hline Pride & $1.027 * *$ & $0.716 *$ & $1.668^{* * *}$ & $1.083 * * *$ & $0.962 *$ & $1.937 * * *$ \\
\hline Party ID * Fear & 0.257 & & & 0.665 & & \\
\hline Party ID * Anger & 0.878 & & & 0.696 & & \\
\hline $\begin{array}{l}\text { Party ID * } \\
\text { Optimism }\end{array}$ & -0.379 & & & -0.067 & & \\
\hline Party ID * Pride & -0.037 & & & -0.427 & & \\
\hline $\begin{array}{l}\text { Knowledge } * \\
\text { Fear }\end{array}$ & & -0.201 & & & -0.044 & \\
\hline $\begin{array}{l}\text { Knowledge * } \\
\text { Anger }\end{array}$ & & -0.138 & & & 0.142 & \\
\hline $\begin{array}{l}\text { Knowledge } * \\
\text { Optimism }\end{array}$ & & 0.191 & & & -0.083 & \\
\hline $\begin{array}{l}\text { Knowledge } * \\
\text { Pride }\end{array}$ & & 0.451 & & & 0.155 & \\
\hline $\begin{array}{l}\text { Previous Govt. * } \\
\text { Fear }\end{array}$ & & & -0.849 & & & 0.580 \\
\hline $\begin{array}{l}\text { Previous Govt. * } \\
\text { Anger }\end{array}$ & & & -0.322 & & & $-1.100^{*}$ \\
\hline $\begin{array}{l}\text { Previous Govt. * } \\
\text { Optimism }\end{array}$ & & & $1.731^{* *}$ & & & $1.720 * *$ \\
\hline $\begin{array}{l}\text { Previous Govt. * } \\
\text { Pride }\end{array}$ & & & $-1.420 *$ & & & $-1.819 * *$ \\
\hline $\begin{array}{l}\text { Gender }(1= \\
\text { male) }\end{array}$ & -0.052 & -0.042 & -0.076 & -0.217 & -0.220 & -0.223 \\
\hline Age & 0.005 & 0.005 & 0.005 & -0.007 & -0.007 & -0.008 \\
\hline $\begin{array}{l}\text { Years of } \\
\text { schooling }\end{array}$ & -0.054 & -0.055 & -0.055 & 0.003 & 0.003 & 0.002 \\
\hline $\begin{array}{l}\text { Socioeconomic } \\
\text { status }\end{array}$ & $0.224 * *$ & $0.234 * *$ & $0.255^{* *}$ & $0.173 *$ & $0.175 *$ & $0.171 *$ \\
\hline Constant & $-1.595 *$ & $-1.514^{*}$ & $-1.486 *$ & -0.696 & -0.711 & -0.654 \\
\hline $\mathrm{N}$ & 1121 & 1121 & 1121 & 1131 & 1131 & 1131 \\
\hline Wald chi2 & $316.68 * * *$ & $291.29 * * *$ & $305.75 * * *$ & $331.42 * * *$ & $306.43 * * *$ & $305.38 * * *$ \\
\hline Pseudo R2 & 0.475 & 0.476 & 0.484 & 0.539 & 0.538 & 0.549 \\
\hline
\end{tabular}

Source: Emotions and Politics Survey, Chile, Dec. 2017 - Jan. 2018 (Segovia and Gamboa, 2018).

$* \mathrm{p}<0,05$; ** $\mathrm{p}<0,01$; *** $\mathrm{p}<0,001$.

Results show that $\mathrm{H} 2 \mathrm{a}$ is partially supported. The evaluation of previous government's performance in its interaction with the emotions measured indicate different 
types of associations. As expected, in the case of the interaction between the evaluation of Bachelet's government and pride, the results indicate a statistically significant coefficient. The likelihood of voting for Piñera is higher when voters feel proud of the candidate and evaluate the previous government negatively. For those who have a good evaluation of Bachelet's government, on the other hand, there is no change in the probability of voting for Piñera.

On the other hand, the interaction of the evaluation of previous government with optimism toward the candidate is statistically significant in both elections, but it indicates an association in the opposite direction to what was expected. The results indicate that the likelihood of voting for Piñera is higher when the candidate arouses optimism. In the absence of optimism towards Piñera, a positive evaluation of previous government decreases the likelihood of voting for Piñera. The interaction with fear is not statistically significant, in both rounds of the elections. In the case of the interaction with anger, the interaction is statistically significant only for the second round, indicating that the likelihood of voting for Piñera increases when voter do not express anger and they have a negative evaluation of Bachelet's government.

The interactions between emotions and party identification, on the other hand, are not statistically significant. The general results hold: a vote for Piñera is more likely among those who felt optimism and pride for the candidate, and less likely among those who felt fear and anger. The results also show that the association of emotions with the vote, especially of optimism and anger, occur both among those who identify with "Chile Vamos" and among those who do not identify with this political coalition. In other words, the interaction between emotions and political identification reinforces the importance of both variables, producing direct and indirect associations with the vote. In the case of pride and fear, the associations are statistically significant only for those who do not identify with the political coalition, respectively reinforcing and diminishing the probability of voting for Piñera. Finally, it is also important to stress that these results occur both in the first and in the second round of the elections. In other words, the relationship between emotions and political identification appears to remain quite stable regardless of the electoral context in which the decision is made.

Finally, regarding the association between emotions and political knowledge, and the vote choice, the results show that these interactions are not statistically significant. Therefore, $\mathrm{H} 2 \mathrm{~b}$ is not supported by the data. The lack of significant interactions between political knowledge and fear might be due to the extremely low levels of knowledge as measured by the survey.

\section{Conclusions}

In this work we investigate the direct and indirect relationships of emotions and the vote choice. We argue that emotions are associated with the vote decision, and that 
they provide new considerations for the study of voting in contexts of low levels of political identification and knowledge. We also argue that emotions have indirect associations with the vote, which are expressed in the interaction between emotions and other variables that are traditionally used in research in this area. The research is based on results obtained in a public opinion survey, conducted with a representative sample of voters after the second round of the 2017 presidential election in Chile. The results obtained provide evidence that supports the hypotheses proposed above.

The first set of hypotheses referred to the direct associations of emotions and the vote. They predicted that the probability of voting for a candidate would decrease if the voter had felt fear or anger towards him or her during the campaign ( $\mathrm{H} 1 \mathrm{a}$ and $\mathrm{H} 1 \mathrm{~b}$ ), while the probability of the vote would increase if the voter had felt pride or optimism $(\mathrm{H} 1 \mathrm{C}$ and $\mathrm{H} 1 \mathrm{~d}$ ). The evidence supports these hypotheses, showing that the vote is directly related to the emotions that the candidates arouse in voters, and in the direction expected. Additionally, the results show that the association of emotions with the vote can be observed in similar magnitudes in different, but related, electoral contexts.

We also argue that not all emotions have the same explanatory capacity. Thus, the results indicate that the emotions with the strongest association with the vote are anger and optimism, and that fear and pride are less important. These results are interesting if we consider, on the one hand, the directionality of emotions and, on the other, the temporality on which they are based. The results indicate that both positive emotions (such as optimism) and negative emotions (such as anger) towards candidates affect the probability of voting for them. There is no exclusive role, then, of emotions with a single directionality on the vote; rather, emotions with different valences will be relevant to different voters.

Regarding the temporality of emotions, anger and pride are emotions that originate in the evaluation of a past event, while optimism and fear are associated with what is expected in the future. The results obtained show that the emotions most relevant for voting are both oriented towards the past (anger) as well as oriented towards the future (optimism).

The second set of hypotheses referred to the indirect role of emotions, measured in terms of their interaction with other important variables to explain the vote. The evidence provides partial support for these hypotheses, indicating that only the interaction of optimism and pride with the evaluation of previous government presents statistically significant coefficients. Substantively, the results indicate that, in the presence of pride, the association of the previous government's evaluation with the vote is greater, as expected. On the other hand, however, the association of the previous government's evaluation with the vote is greater in the absence of optimism.

In considering these results, two other points should be highlighted. In the first place, one must ask what these results suggest in the current context of the Chilean political system and its future development. The evidence provided should be considered 
carefully. Although emotions are not the only explanatory variable of the vote in Chile as we have stressed, it is certainly clear that they matter. And their importance can only increase with the events of the second half of 2019, in which trust and identification with representative institutions, especially the parties, reached an all-time low. This, in turn, has been reflected in a low capacity to lead the political process. In this sense, it cannot be ruled out that, in the future, spaces will increase for the emergence of leaderships that seek to develop structures or forms of representation different from those that until now have predominated in the Chilean political system. And in which the recourse to emotions occupies a central place as the basis of the relationship between representatives and represented.

In the second place, these results open the door to some interesting questions for future research. First, if political action can be related to both positive and negative affective evaluation of candidates, it is important to address the question of what voter characteristics lead to the greater or lesser relevance of positive or negative emotions in their vote. It is also important, secondly, to consider how emotions affect other decisions or political actions that citizens may take. To what extent are the vote and other decisions such as participation in protests, party membership, etc., associated with positive or negative emotions? Third, it is important to consider when the past or the future, and the emotions they arouse, are more relevant to the vote, and to what extent those who vote in response to different types of emotions differ. Finally, it is important to advance in determining if these results are replicated or not in other electoral contexts or in other types of political decision.

\section{References}

ABELSON, R. P., et al. "Affective and semantic components in political person perception". Journal of Personality and Social Psychology, vol. 42, no 4, p. 619-663, 1982.

ANDEWEG, R. B.; FARRELl, D. M. Legitimacy decline and party decline. In: VAN HAM, C., et al. (eds.). Myth and reality of the legitimacy crisis. Oxford: Oxford University Press, 2017.

BARGSTED, M.; SOMmA, N. "Social cleavages and political dealignment in contemporary Chile, 19952009". Party Politics, vol. 22, nº 1, p. 105-124, 2016.

Berelson, B. R.; LAzARSfeld, P. F.; MCPhee, W. N. Voting: a study of opinion in a presidential campaign. Chicago: University of Chicago Press, 1954.

BRADER, T. The emotional foundations of democratic citizenship. In: BERINSKY, A. J. (ed.). New directions in public opinion. New York: Routledge, 2012.

Brader, T.; Marcus, G. E. Emotion and political psychology. In: Huddy, L.; SEARS, D. O.; LeVy, J. S. (eds.). The Oxford handbook of political psychology. $2^{\text {nd }}$ ed. Oxford: Oxford University Press, 2013.

CampBelL, A., et al. The American voter. Chicago: The University of Chicago Press, 1960. 
CAPELOS, T. Understanding anxiety and aversion: the origins and consequences of affectivity in political campaigns. In: DEMERTZIS, N. (ed.). Emotions in politics - The affect dimension in political tension. New York: Palgrave Macmillan, 2013.

Chong, D. Degrees of rationality in politics. In: HudDY, L.; SEARS, D. O.; LeVY, J. S. (eds.). The Oxford handbook of political psychology. $2^{\text {nd }}$ ed. Oxford: Oxford University Press, 2013.

CONVERSE, P. E. The nature of belief systems in mass publics. In: APTER, D. E. (ed.). Ideology and discontent. New York: The Free Press of Glencoe, 1964.

p. $331-153,2000$.

. "Assessing the capacity of mass electorates". Annual Review of Political Science, vol. 3,

Delli Carpini, M. X.; KeETeR, S. "Stability and change in the U.S. public's knowledge of politics".

Public Opinion Quarterly, vol. 55, p. 583-612, 1991.

DEMERTZIS, N. Theorizing the emotions-politics nexus. In: DEMERTZIS, N. (ed.). Emotions in politics The affect dimension in political tension. New York: Palgrave Macmillan, 2013.

Dinas, E. The evolving role of partisanship. In: ARZHeimer, K.; EVANS, J.; LeWIS-BeCK, M. S. (eds.). The Sage handbook of electoral behaviour. Los Angeles: Sage, 2017.

Dixon, T. "Emotion: the history of a keyword in crisis". Emotion Review, vol. 4, no 4, p. 338-344, 2012.

Downs, A. An economic theory of democracy. Harper \& Row, 1957.

Druckman, J. N.; LUPIA, A. "Preference formation". Annual Review of Political Science, vol. 3, p. 1-24, 2000.

DRUCKMAn J. N.; MCDERMOTT, R. "Emotion and the framing of risky choice". Political Behavior, vol. 30, n० 3, p. 297-321, 2008.

ELSTER, J. Explaining social behavior: more nuts and bolts for the social sciences. Cambridge: Cambridge University Press, 2007.

FIORINA, M. Retrospective voting in American national elections. New Haven: Yale University Press, 1981.

Freedom House. Freedom in the world 2018. Democracy in crisis. Freedom House, 2018. Available at: <https://freedomhouse.org/report/freedom-world/freedom-world-2018.> Access: 12 jan. 2019.

GaRSON, G. D. Logistic Regression: binary and multinomial. Asheboro: Statistical Publishing Associates, 2016.

GéLINEAU, F.; SINGER, M. M. The economy and incumbent support in Latin America. In: CARLIN, R. E.; SingER, M. M.; ZECHMEISTER, E. J. (eds.). The Latin American voter: pursuing representation and accountability in challenging contexts. Ann Arbor: The University of Michigan Press, 2015.

GILENS, M. Two-thirds full? Citizen competence and democratic governance. In: BERINSKY, A. J. (ed.). New directions in public opinion. New York: Routledge, 2012.

GREen, D. P.; BALTES, S. Party identification: meaning and measurement. In: ARZHeimer, K.; EVANS, J.; LEWIS-BECK, M. S. (eds.). The Sage handbook of electoral behaviour. Los Angeles: Sage, 2017.

GROENENDYK, E. "Current emotion research in political science: how emotions help democracy overcome its collective action problem". Emotion Review, vol. 3, no 4, p. 455-463, 2011. 
BETWEEN KNOWING AND FEELING: EMOTIONS AND THE VOTE IN THE 2017 CHILEAN PRESIDENTIAL ELECTION

Hetherington, M. Partisanship and polarization in contemporary politics. In: Berinsky, A. J. (ed.). New directions in public opinion. $2^{\text {nd }}$ ed. New York: Routledge, 2016.

HUDDY, L., et al. "Threat, anxiety, and support of antiterrorism policies". American Journal of Political Science, vol. 49, p. 593-608, 2005.

Huddy, L.; Feldman, S.; CASSESE, E. On the distinct political effects of anxiety and anger. In: CRIGLeR, A., et al. (eds.). The political dynamics of feeling and thinking. Chicago: University of Chicago Press, 2007.

INBAR, Y., et al. "Disgust sensitivity, political conservatism, and voting". Social Psychological and Personality Science, vol. 3, no 5, p. 537-544, 2012.

JASPER, J. M. "Emotions and social movements: twenty years of theory and research". Annual Review of Sociology, vol. 37, p. 1-9, 2011.

. "Constructing indignation: anger dynamics in protest movements". Emotion Review, vol. 6, no 3, p. 208-213, 2014.

JUST, M. R.; CRIgLER, A. N.; BELT, T. L. Don't give up hope: emotions, candidate appraisals, and votes. In: NeumAN, W. R., et al. The affect effect: dynamics of emotion in political thinking and behavior. Chicago: The University of Chicago Press, 2007.

Kinder, D. R. "Communication and opinion". Annual Review of Political Science, vol. 1, p. 167-197, 1998.

KrAmpen, G. "Transition of adolescent political action orientations to voting behavior in early adulthood in view of a social-cognitive action theory model of personality". Political Psychology, vol. 21, p. 277-297, 2000.

LADD, J.; LENZ, G. S. "Reassessing the role of anxiety in vote choice". Political Psychology, vol. 29, no 2, p. 275-296, 2008.

LAU, R. R.; REDLAWSK, D. P. How voters decide: information processing during election campaigns. Cambridge: Cambridge University Press, 2006.

LeRneR, J. S.; Keltner, D. "Beyond valence: Toward a model of emotion-specific influences on judgement and choice". Cognition and Emotion, vol. 14, p. 473-493, 2000.

LeRner, J. S., et al. "Emotion and decision making". Annual Review of Psychology, vol. 66, p. 799823,2015

LEWIS-BECK, M. S.; COSTA LOBO, M. The economic vote: ordinary vs. extraordinary times. In: ARZHeimer, K.; EVANS, J.; LeWIS-BeCK, M. S. (eds.). The Sage handbook of electoral behaviour. Los Angeles: Sage, 2017.

LODGE, M.; TABER, C. S. The rationalizing voter. Cambridge: Cambridge University Press, 2013.

LUPIA, A. "Shortcuts versus encyclopedias: information and voting behavior in California insurance reform elections". American Political Science Review, vol. 88, no 1, 63-76, 1994.

LUPU, N. Partisanship in Latin America. In: CARLin, R. E.; Singer, M. M.; ZeChMeISTER, E. J. (eds.). The Latin American voter: pursuing representation and accountability in challenging contexts. Ann Arbor: The University of Michigan Press, 2015.

MACKUEN, M., et al. The third way: the theory of affective intelligence and American democracy. In: Neuman, W. R., et al. (eds.). The affect effect: dynamics of emotion in political thinking and behavior. Chicago: The University of Chicago Press, 2007. 
MAINWARING, S.; TORCAL, M. Party system institutionalization and party system theory after the third wave of democratization. In: KATZ, R. S.; CROTTY, W. (eds.). Handbook of party politics. London: Sage Publications, 2006.

MARCUS, G. E. The theory of affective intelligence and liberal politics. In: DemerTZIS, N. (ed.). Emotions in politics - The affect dimension in political tension. New York: Palgrave Macmillan, 2013.

MARCUS, G. E.; MACKUEN, M. "Anxiety, enthusiasm and the vote: the emotional underpinnings of learning and involvement during presidential campaigns". American Political Science Review, vol. 87, no 3, p. 672-685, 1993.

Marcus, G. E.; Neuman, W. R.; MacKuen, M. Affective intelligence and political judgment. Chicago: University of Chicago Press, 2000.

Miller, P. R. "The emotional citizen: emotion as a function of political sophistication". Political Psychology, vol. 32, no 4, p. 575-600, 2011.

Moors, A., et al. "Appraisal theories of emotion: state of the art and future development". Emotion Review, vol. 5, no 2, p. 119-124, 2013.

Mulligan, K.; Scherer, K. R. "Toward a working definition of emotion". Emotion Review, vol. 4, no 4, p. 345-357, 2012.

Neuman, W. R., et al. Theorizing affect's effects. In: Neuman, W. R., et al. (eds.). The affect effect: dynamics of emotion in political thinking and behavior. Chicago: The University of Chicago Press, 2007.

OtTAti, V.; Steenbergen, M.; Riggle, E. "The cognitive and affective components of political attitudes: measuring the determinants of candidate evaluations". Political Behavior, vol. 14, no 4, p. 423-442, 1992.

PARKer, M. T.; ISBELL, L. M. "How I vote depends on how I feel: the differential impact of anger and fear on political information processing". Psychological Science, vol. 21, no 4, p. 548-550, 2010.

PÉREZ, O. J. The impact of crime on voter choice in Latin America. In: CARLIN, R. E.; SingER, M. M.; ZeChMEISTER, E. J. (eds.). The Latin American voter: pursuing representation and accountability in challenging contexts. Ann Arbor: The University of Michigan Press, 2015.

Petersen, M. B. "Distinct emotions, distinct domains: anger, anxiety and perceptions of intentionality". The Journal of Politics, vol. 72, no 2, p. 357-365, 2010.

Popkin, S. L.; Dimock, M. A. Political knowledge and citizen competence. In: ElkIN, S. K.; SolTAN, K. E. (eds.). Citizen competence and democratic institutions. University Park: Penn State University Press, 1999.

Redlawsk, D. P.; Civettini, A. J. W.; LAU, R. R. Affective intelligence and voting: information processing and learning in a campaign. In: NEUMAN, W. R., et al. (eds.). The affect effect: dynamics of emotion in political thinking and behavior. Chicago: The University of Chicago Press, 2007.

Redlawsk, D. P.; Pierce, D. R. Emotions and voting. In: ArZheimer, K.; Evans, J.; LeWis-BeCK, M. S. (eds.). The Sage handbook of electoral behaviour. Los Angeles: Sage, 2017.

Rico, G.; GUINJOAN, M.; ANDUIZA, E. "The emotional underpinnings of populism: how anger and fear affect populist attitudes". Swiss Political Science Review, vol. 23, no 4, p. 444-461, 2017.

Sabucedo, J. M.; Vilas, X. "Anger and positive emotions in political protest". Universitas Psychologica, vol. 13, no $^{\circ}$, p. 829-838, 2014. 
SAn MARtín, J. J. P. "Campaña y emociones. Un análisis de la franja electoral de las elecciones presidenciales de Chile en 2017". Tesis para optar al grado de Licenciado en Ciencia Política. Universidad Diego Portales, Santiago, 2018.

Scarantino, A. "How to define emotions scientifically". Emotion Review, vol. 4, no 4, p. 358-368, 2012.

SeARS, D. O.; Brown, C. Childhood and adult political development. In: Huddy, L.; SeARS, D. O.; LEVY, J. S. (eds.). The Oxford handbook of political psychology. $2^{\text {nd }}$ ed. Oxford: Oxford University Press, 2013.

SEgoviA, C. "Desigualdad de información: una exploración de los antecedentes del conocimiento político en Chile". Psykhé, vol. 25, no 2, p. 1-16, 2016.

SegoviA, C.; GamboA, R. "Primera Encuesta Nacional Emociones y Política en Chile". [Archivo de Datos]. Santiago: Proyecto Fondecyt 1170335, 2018.

Silva, T.; Whitten, G. D. Clarity of responsibility and vote choice. In: ARZHEIMER, K.; EvANS, J.; LeWISBECK, M. S. (eds.). The Sage handbook of electoral behaviour. Los Angeles: Sage, 2017.

SPEZIO, M. L.; AdOLPHS, R. Emotional processing and political judgment: toward integrating political psychology and decision neuroscience. In: NEUMAN, W. R., et al. (eds.). The affect effect: dynamics of emotion in political thinking and behavior. Chicago: The University of Chicago Press, 2007.

Steenbergen, M. R.; Ellis, C. Fear and loathing in American elections: context, traits, and negative candidate affect. In: REDLAWSK, D. P. (eds.). Feeling politics: emotion in political information processing. New York: Palgrave Macmillan, 2006.

THE ECONOMIST. Democracy Index 2018: Me too? Political participation, protest and democracy, 2018. Available at:

<https://www.eiu.com/public/topical_report.aspx?campaignid=Democracy2018>. Access: 12 jan. 2019.

ToRo, S. Y.; VAlenzUela, M. "Chile 2017: ambiciones, estrategias y expectativas en el estreno de las nuevas reglas electorales". Revista de Ciencia Política, vol. 38, no 2, p. 207-232, 2018.

VAlEntino, N. A., et al. "Is a worried citizen a good citizen? Emotions, political information seeking, and learning via the internet". Political Psychology, vol. 29, no 2, p. 247-273, 2008.

"Election night's alright for fighting: the role of emotions in political participation". The Journal of Politics, vol. 73, no 1, p. 156-170, 2011.

Weber, C. "Emotions, campaigns, and political participation". Political Research Quarterly, vol. 66, no 2, p. 414-428, 2012.

WeEKS, B. E. "Emotions, partisanship, and misperceptions: how anger and anxiety moderate the effect of partisan bias on susceptibility to political misinformation". Journal of Communication, vol. 65, p. 699-719, 2015.

YATES, H. E. The politics of emotions, candidates and choices. New York: Palgrave Pivot, 2016.

ZALLER, J. R. The nature and origins of mass opinion. Cambridge: Cambridge University Press, 1992. 


\section{Resumo}

Entre o saber e o sentimento: as emoções e o voto na eleição presidencial chilena de 2017

Como os cidadãos decidem em quem votar nas eleições? As respostas tradicionais enfocam o papel do conhecimento político, identificação de partidos e avaliações do desempenho passado dos governos como variáveis explicativas. Neste artigo, avaliamos um argumento alternativo: o papel desempenhado pelas emoções. Usando dados de uma pesquisa realizada após as eleições gerais chilenas de dezembro de 2017, investigamos a associação das emoções com o voto em Sebastián Piñera e como as emoções interagem com outros fatores relevantes que se correlacionam com o voto. Concluímos que no Chile, juntamente com a identificação do partido e a avaliação de governos anteriores, as emoções dos eleitores em relação aos candidatos estão associadas à decisão do voto.

Palavras-chave: emoções; voto; identificação partidária; conhecimento político; avaliação retrospectiva; Chile

\section{Resumen}

Entre el saber y el sentir: emociones y voto en la elección presidencial chilena de 2017

¿Cómo deciden los ciudadanos a quién votar en una elección? Las respuestas tradicionales se centran en el papel del conocimiento político, la identificación de los partidos y la evaluación del desempeño pasado de los gobiernos como variables explicativas. En este estudio evaluamos un argumento alternativo: el papel desempeñado por las emociones. Utilizando datos de una encuesta realizada después de las elecciones generales chilenas de diciembre de 2017, este artículo investiga la relación de las emociones con el voto por Sebastián Piñera y cómo las emociones interactúan con otros factores relevantes que se correlacionan con el voto. Concluimos que en Chile, junto con la identificación de los partidos y la evaluación retrospectiva, las emociones de los electores hacia los candidatos están asociadas a su decisión de por quién votar.

Palabras clave: emociones; voto; identificación partidaria; conocimiento político; evaluación retrospectiva; Chile

\section{Résumé}

Entre savoir et sentiment: émotions et vote à l'élection présidentielle chilienne 2017

Comment les citoyens décident-ils pour qui voter lors d'une élection? Les réponses traditionnelles mettent l'accent sur le rôle des connaissances politiques, l'identification des partis et les évaluations des performances passées des gouvernements en tant que variables explicatives. Dans cette étude, nous évaluons un argument alternatif: le rôle joué par les émotions. À l'aide des données d'une enquête réalisée à la suite des élections générales chiliennes de décembre 2017, cet article examine l'association des émotions avec le vote pour Sebastián Piñera et la façon dont les émotions interagissent avec d'autres facteurs pertinents en corrélation avec le vote. Nous concluons qu'au Chili, avec l'identification des partis et l'évaluation des gouvernements antérieurs, les émotions des électeurs envers les candidats sont associées à la décision de qui voter.

Mots-clés: émotions; vote; identification du parti; connaissances politiques; évaluation rétrospective; Chili

Artigo submetido à publicação em 17 de julho de 2019. Versão final aprovada em 29 de junho de 2020.

Opinião Pública adota a licença Creative Commons CC-BY. 